\title{
Pedological Characteristics of Cucumber (Cucumis sativus L) Cropsin Mediterranean Environment (Huete, Spain)
}

\author{
Jiménez Ballesta $\mathbf{R}^{\mathbf{1}^{*}}$, García Navarro $\mathrm{FJ}^{2}$, García-Giménez $\mathbf{R}^{1}$ \\ ${ }^{1}$ Department of Geology and Geochemistry, Autónoma University of Madrid, Spain. \\ ${ }^{2}$ Department of Science and Technology, Agroforestry and Genetics, Castilla-La Mancha University, Ciudad Real, Spain.
}

Received: September 17, 2017; Accepted: November 21, 2017; Published: December 04, 2017

*Corresponding author: Jiménez Ballesta R, Department of Geology and Geochemistry, Autónoma University of Madrid, Spain, E-mail: raimundo. jimenez@uam.es

\begin{abstract}
Substrate nutrient and moisture management are two major concerns in the cultivation of Cucumis sativus L cropsinHuete. Entisols (Soil Survey Staff) or Regosols (FAO-UNESCO-ISSS) are the main soil types in this area. These soils are characterized by being moderately deep, they have medium to moderately thick textures and they are on sandy subsoils or sandy loam. The soils are moderately permeable and are susceptible to saturation during periods of prolonged rainfall. The soils are generally fertile are susceptible to mechanized tillage and rarely contain a stony phase.
\end{abstract}

Keywords: Cucumber Sativus L; Adaptation; Pedological; Huete; Mediterranean Environment:

\section{Introduction}

Agro-ecological engineering approaches aimed at the design and exploration of alternative land use systems on different scales can support the identification of appropriate land use options [1]. According to Fresco and Kroonenber, the characteristics of the agro-ecological processes depend on the scale in question [2].

Cucumber is a native vegetable of the tropical regions of South Asia, from where it spread to Europe and America. The botanical name for cucumber is Cucumis sativus L As for melon, wátermelon and squash, cucumber belongs to the family Cucurbitaceae [3]. Cucurbitaceae is a reasonably large family of about 130 genera and 900 species $[4,5]$. Of these species, around 30 from 9 genera are cultivated. All Cucurbitaceae are frost-sensitive and the family is confined to the warmer regions of the globe. Cucumber is cultivated on around seven million hectares worldwide and more than half are produced in Asia, 26\% in Europe and the rest in Africa and America [6]. Spain wasone of the first countries to produce cucumber in the European Union, with an estimated production volume of between 700,000 and 800,000 tonnes.

Castilla La Mancha (Central Spain) is one of the Spanish regions in which different cucurbetacea (melon, watermelon, cucumber)are produced. These areas are traditionally dedicated to irrigated farming. Cucumber (Cucumis sativus L) from Huete
(Cuenca, Spain) is highly valued gastronomically and it is used in salads and entrees. The aim of the work described here wasto review the pedological characteristics and adaptability in the case of Huete cucumber.

\section{Material And Methods}

\section{The Site}

The area under investigation surrounds the village of Huete, a municipality in the Cuenca region of Alcarria (Castilla-La Mancha, Spain), located on the eastern and southern slopes of Castillo hill (Figure 1) between the courses of the rivers Borbotónand Major. The elevation of Huete is $809 \mathrm{msnm}$.

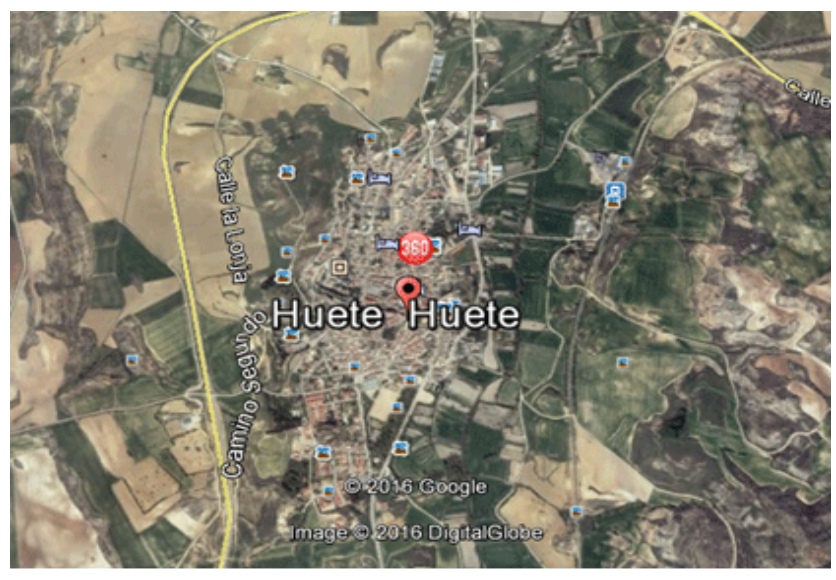

Figure 1: Location of the area

In geological terms, the tertiary that borders the soils of the meadow where the Huete cucumber is planted is represented by materials of the Paleogene and Neogene periods and it has continental environments and varied lithology (conglomerates, sandstones, clays, gypsum, limestone). The quaternary (where the crop is located) is formed by deposits of erosion and filling 
(basically alluvial deposits from the valley, although sometimes in conjunction with coluvions and hillside deposits).

The average annual temperature in Huete is $12.40 \mathrm{C}$ and precipitation has an average annual value of $451 \mathrm{~mm}$. It can be seen from the climatic diagram that there is a period of water deficit that normally coincides with the period of cultivation of the cucumber.

\section{Soil Sampling}

The samples were taken from profiles opened with a caterpillar machine (approximately $1 \times 1.5$ meters in area and 2 meters in depth). In all cases the soil profile was conditioned using manual tools. The profiles (Table 1) were described according to FAO guidelines and samples were subsequently collected from each horizon for all the profiles and were air dried and sieved $(<$ $2 \mathrm{~mm}$ ) prior to analysis [7].

Table 1. Some characteristics of analyzed soil profiles.

\begin{tabular}{|c|c|c|c|c|c|c|c|}
\hline \multicolumn{8}{|c|}{ PROFILE $1 \quad(X-527.062 .44-4.445 .097,8)$} \\
\hline $\begin{array}{l}\text { Soil Type } \\
\text { (FA0/ST) }\end{array}$ & Morphology & $\begin{array}{c}\text { Parent } \\
\text { material }\end{array}$ & $\begin{array}{c}\text { Vegetation/ } \\
\text { Use }\end{array}$ & Topography & Slope & Drainage & Stoniness \\
\hline $\begin{array}{c}\text { Haplic Regosol / Typic } \\
\text { Xerorthent }\end{array}$ & $\begin{array}{l}\text { Ap }(0-36 \mathrm{~cm}) \\
\text { C1 }(36-83 \mathrm{~cm}) \\
\text { C2 }(>83 \mathrm{~cm})\end{array}$ & $\begin{array}{c}\text { Fluvial } \\
\text { material/ } \\
\text { Marls }\end{array}$ & $\begin{array}{l}\text { Irrigated } \\
\text { farming }\end{array}$ & $\begin{array}{l}\text { Botton } \\
\text { valley }\end{array}$ & $\begin{array}{c}\text { Flat }(\mathrm{C}- \\
0)\end{array}$ & $\begin{array}{l}\text { Well drained } \\
\qquad(\mathrm{C}-4)\end{array}$ & $\begin{array}{c}\text { No stoniness } \\
\text { (C-0) }\end{array}$ \\
\hline \multicolumn{8}{|c|}{ PROFILE 2 (X-527.057.81 - 4.446.008) } \\
\hline $\begin{array}{l}\text { Soil Type } \\
\text { (FA0/ST) }\end{array}$ & Morphology & $\begin{array}{c}\text { Parent } \\
\text { material }\end{array}$ & Vegetation & Topography & Slope & Drainage & Stoniness \\
\hline $\begin{array}{c}\text { Haplic Regosol/ Typic } \\
\text { Xerorthent }\end{array}$ & $\begin{array}{l}\text { Ap }(0-45 \mathrm{~cm}) \\
\text { C1 }(45-68 \mathrm{~cm}) \\
\text { C2 }(>68 \mathrm{~cm})\end{array}$ & $\begin{array}{l}\text { Fluvial } \\
\text { material/ } \\
\text { Marls }\end{array}$ & $\begin{array}{l}\text { Irrigated } \\
\text { farming }\end{array}$ & $\begin{array}{l}\text { Botton } \\
\text { valley }\end{array}$ & $\begin{array}{c}\text { Flat }(\mathrm{C}- \\
0)\end{array}$ & $\begin{array}{l}\text { Well drained } \\
\qquad(\mathrm{C}-4)\end{array}$ & $\begin{array}{c}\text { No stoniness } \\
\text { (C-0) }\end{array}$ \\
\hline
\end{tabular}

\section{Analytical Methods}

Soil $\mathrm{pH}$ was measured in a 1:1 soil:water suspension (Peech, et al.) and electrical conductivity in a 1:5 soil: water suspension (Richards, et al.) $[8,9]$. The exchangeable capacity was measured by the method described by Thomas [10]. The soil organic matter was determined using the method described by Anne [11]. The total $\mathrm{CaCO}_{3}$ content was determined by the Bernard calcimeter method using $4 \mathrm{M} \mathrm{HCl}$. Finally, total nitrogen was measured by Kjeldahl's method and available phosphorus was measured by the Olsen method $[12,13]$.

\section{Results and Conclusions}

The relevant data for the soil samples are summarized in figure 2. The organic matter content is moderate, tending to low $(<3 \%)$. Chemically, the $\mathrm{pH}$ is optimum (7.55 to 7.96 ) and the catión Exchange capacity $(43.6-29.3 \mathrm{cmol} / \mathrm{kg}$ ) is acceptable. The texture is sandy-loam with a low percentage of gravel, although within the study area deep pockets of clay-loam were frequently found. The texture of the analyzed soils reveals that they have a uniform texture, which is predominantly loam-loamy. The cation exchange capacity ranges from 29.3 to $43.6 \mathrm{cmol} / \mathrm{kg}$ and this is dominated by $\mathrm{Ca}^{2+}$. The carbonate content (which is lower in profile 1 than in profile 2) ranges between 21.5 and $63.6 \%$. The soil is deficient in phosphorus (varies between 5.4 and $14.6 \mathrm{ppm}$ ) and a similar trend was observed for the $\mathrm{N}$ content.

However, one of the most significant features of the soils of the area dedicated to cucumber cultivation is the presence of a certain level of salinity. The Huete cucumber seems able to tolerate greater levels of soil salinity than other species. Barage states that there are wild accessions of cucurbitaceae that are salt tolerants [14]. The cucumbers are irrigated with water that has moderate electrical conductivity and there is no appreciable decrease in yield. (Sanden, et al.) pointed out that a soil electrical conductivity up to $6 \mathrm{dS} / \mathrm{m}$ does not have a detrimental effect on the growth of pistachio and the scenario could be similar in Huete; in the case of pistachio only when the electrical conductivity of the soil exceeds $8 \mathrm{dS} / \mathrm{m}$ was a decrease in yield of approximately $50 \%$ observed [15]. In the soils under investigation the electrical conductivity values range between 1.7 and $2.2 \mathrm{dS} / \mathrm{m}$ and the values were slightly higher in profile 1 than in 2 .Given the salinity data it is possible that this low level of salinity may be one of the characteristics that gives Huete cucumber its characteristic taste, an aspect that would need to be investigated more deeply.

The soils were developed from materials deposited by river currents and are generally identified as Entisols or Regosols (FAO-UNESCO-ISRI) [16,17]. As a consequence of their relatively low genetic development, these soils do not have clearly defined diagnostic horizons. However ,they are characterized as being moderately deep, they have medium and moderately thick textures and are on sandy subsoils or sandy loam. The soils are also moderately permeable and are susceptible to saturation during periods of prolonged rainfall. The soils are generally fertile, susceptible to mechanized tillage and rarely contain a stony phase. 


\section{Acknowledgements}

The authors are grateful to the CALTERRAS FOUNDATION for providing some data and assistance during work fields. The authors also thank Jorge Paredes Guijarro and José Maria Sanchez Collada.
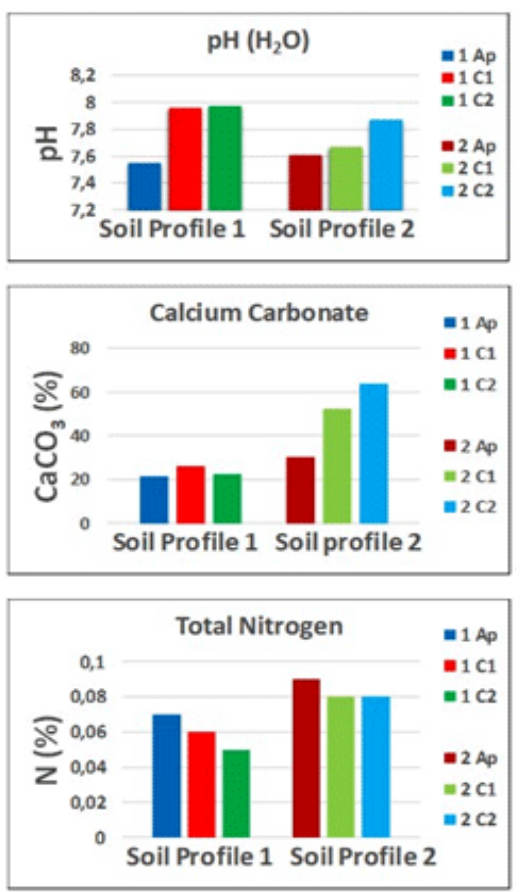
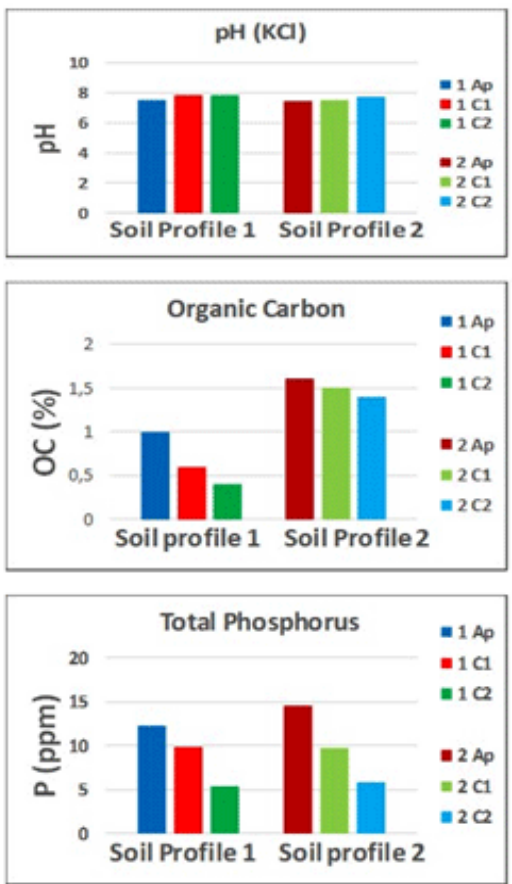
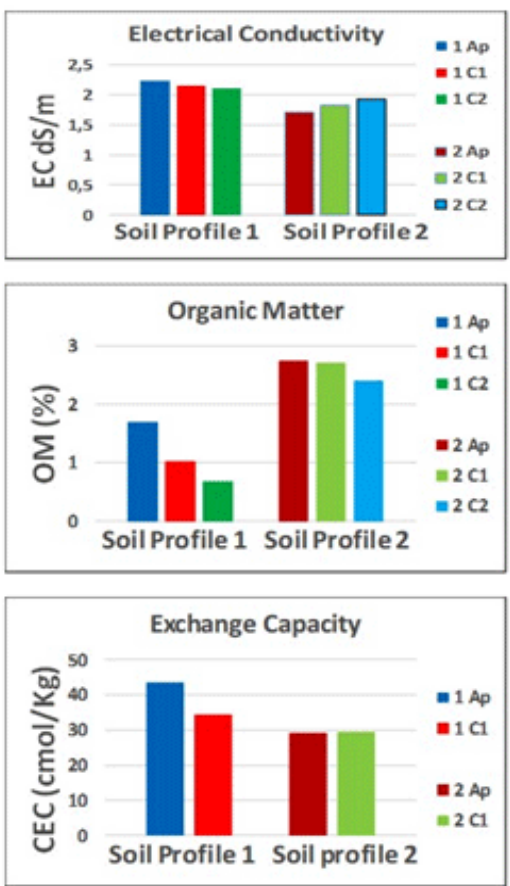

Figure 2: Selected properties measured in soil samples: $\mathrm{pH}$, EC electrical conductivity (dS/m), OC organic carbon (\%), OM organic matter (\%), calcium carbonate (\%), $\mathrm{N}$ total nitrogen, $\mathrm{P}$ total phosphorus, CEC exchange capacity $(\mathrm{cmol} / \mathrm{kg})$.

\section{References}

1. Hengsdijk H,van Ittersum MK. Formalizing agro-ecological engineering for future-oriented land use studies. European Journal of Agronomy.2003;19(4):549-562.

2. Fresco L.O, Kroonenberg S.B. Time and spatial scales in ecological sustainability. Land use Policy 9.1992;155-168.

3. Jelaska S. (1986). Cucurbits. In: Bajaj YPS (eds). Biotechnology in Agriculture and Forestry 2. Crops I: 371-386. Springer-Verlag. Berlin.

4. Jeffrey C. A review of the Cucurbitaceae. Botanical Journal of the Linnean Society.1980;81:233-247. doi:10.1111/j.1095-8339.1980. tb01676.x

5. Jeffrey C. 1990. Systematics of the Cucurbitaceae, an overview. In: Bates DM, Robinson RW,3-9.

6. Gonsalves C,Xue B,Yepes M,Fuchs M,Ling K,NambaS,Chee P.,et all. Transferring cucumber mosaic virus-white leaf strain coat protein gene into Cucumismelo $L$. and evaluating transgenic plants for protection against infections. J. Amer. Soc. Hort. Sci.1994;119(2):345-355.

7. FAO. Guidelines for soil description. FAO/UNESCO. Rome,4th edition.2007;

8. Peech M. Hydrogen-ion activity. In C.A. Black et al., Eds., Methods of Soil Analysis.Part 2. American Society of Agronomy, Madison, WI, pp.1965;914-926.

9. Richards LA. Diagnosis and Improvement of Saline and Alkaline Soils. United States Salinity Laboratory Staff. Agricultural Handbook No 60. United States Department of Agriculture, 160p.1954
10. Thomas G.W. (1982). Exchange cations. In A. L. Page, R. H. Miller y D.R. Keeney (eds.): methods of soil analysis, Part 2 (pp 159-165). Madison, Wisconsin. American society of Agronomy/Soil Science Society of America.

11. Anne A.Sur le dosage rapid du carboneorganique de sols. Annals of Agronomy 2.1945;161-172.

12. Bremner JM, and Mulvaney CS.Nitrogen Total. In: Page A.L. (Ed.) Methods of Soil Analysis Part 2, Chemical and Microbiological Properties, American Society of Agronomy and Soil Science Society of America, Madison, WI.1982;621-622.

13. Olsen SR ,Cole CV, Watanabe FS, Dean LA.Estimation of Available Phosphorus in Soils by Extraction with Sodium Bicarbonate. US Department of Agriculture CIRC.1954;939.

14. Baragé M.Identificación de fuentes de tolerancia a la salinidad y al estrés hídrico en especies silvestres de la familia Cucurbitaceae. $\mathrm{PhD}$ thesis, Universidad Politécnica de Valencia. 219 pp.2002.

15. Sanden BL, Ferguson L, Reyes HC ,Grattan SC. Effect of salinity on evapotranspiration and yield of San Joaquin Valley pistachios. Proceedings of the IVth International Symposium on Irrigation of Horticultural Crops, Acta Horticulturae.2004;664:583-589.

16. Soil Survey Staff. Keys for taxonomy, 10th edition USDA-NCRS.2006.

17.FAO-ISSS-ISRIC.World reference base for soil resources 2006. A framework for international classification, correlation and communication. World Soil Resources Report No 103.2006; 